\title{
Critical Digital Literacy: Technology in Education Beyond Issues of User Competence and Labour-Market Qualifications
}

\author{
Holger Pötzsch
}

UiT Tromsø, Tromsø, Norway, holger.potzsch@uit.no, https://en.uit.no/om/enhet/ansatte/person?p_document_id=43820\&p_dimension_id=210121

\begin{abstract}
The present contribution conducts an intervention in the study and practice of digital and media literacy. After reviewing key tenets of recent debates, I advance a specific understanding of the concept - critical digital literacy - that, as I argue, comprehensively addresses issues of knowledge, competencies, and skills in relation to digital technologies. In particular, I posit that critical thinking about educational and other values of 'the digital' needs to take structural aspects of the technology into account that are often eschewed in instrumental or commercially-driven approaches. To prepare pupils for their future lives requires a widest possible contextualisation of technology, including issues of exploitation, commodification, and degradation in digital capitalism. Finally, I make concrete suggestions for constructive uses of technology in teaching and learning.
\end{abstract}

Keywords: digital literacy, education, technology, digital competencies and skills, critical approaches, digital capitalism, practice

Acknowledgement: I would like to thank Hilde Brox (UiT Troms $\varnothing$ ) and Michael Meyen, Mandy Tröger, Kerem Schamberger, Natalie Berner, Daria Gordeieva, and Sevda Can Arslan (Ludwig-Maximilians-Universität München) for their comments on earlier versions of this manuscript. Many thanks also to Robert W. Gehl and a second anonymous reviewer for their excellent suggestions and constructive criticism.

\section{Introduction}

In his book Silent Media, ${ }^{1}$ Roberto Simanowski (2018) warns against a thoughtless implementation of digital technologies in educational settings. Rearticulating themes that have been highlighted earlier by, for instance, Livingstone (2004; 2012), Buckingham (2006; 2007), Selwyn (2010), Beck (2011), Bigum, Bulfin and Johnson (2015), and Bayne (2015), Simanowski argues that, today, schools do not necessarily need more technology in classrooms or new skill sets for teachers. Rather, pupils and students should learn to critically reflect upon and properly contextualise technologies that have enormous implications for their lives not only as future part of a work force but also as citizens and fully-fledged individuals. As Buckingham $(2006,263)$ puts it, if we want to use "digital media to teach, we need to equip students to understand and to critique these media: we cannot regard them simply as neutral means of delivering information". I take such positions as a point of departure for an exploration of the field of critical digital literacy.

This contribution asks how critical digital literacy can be defined and how it can be realised in educational settings. Firstly, I conduct a literature review to assess the

\footnotetext{
1 The original German title is Stumme Medien. All translations from German by Holger Pötzsch.
} 
current state of research on digital literacy. I identify a need to direct more attention to a specifically critical notion of the concept that not only covers new competencies and skills required to responsibly and efficiently use digital technologies, but also includes the ability to contextualise this use with an eye on capitalist dynamics, environmental ramifications, and individual empowerment. Secondly, I use this framework to critique the current adoption of costly corporate hard-and software applications in schools and universities and question the need and effect of such large-scale investments. Finally, I offer a series of concrete hands-on recommendations on how critical digital literacy can be conveyed and fostered in contemporary education.

\section{Disentangling Literacies}

At the heart of communication lies the concept of literacy. Traditionally, literacy has referred to alphabetisation and the ability to use language in reading and writing. Since the 1990s, media and literacy researchers have begun to formulate a wider understanding of the concept to account for new varieties of texts emerging in the contexts of globalisation and the development of digital media (see for instance Cazden et al. 1996; Kress 2003; Lankshear and Knobel 2008; Kern 2015). Gradually, the focus has shifted towards multiple situated literacies that account for a variety of textual practices applicable in different contexts, media, and modalities (such as written, audio-visual or hyperlinked, and in correspondence with requirements posed by particular communicative situations, genres or sociolects). This capacity to use different media in a variety of ways to receive, produce, and disseminate information has been seen as crucial for individuals' chances of personal development and participation in increasingly complex and networked societies. The question of what abilities are needed in order to identify, understand, interpret, create and communicate via digital media - what constitutes a specifically digital form of literacy - has been at the heart of much recent educational debate.

Constituting a special form of media literacy, the term digital literacy has been discussed for some time now (for overviews see for instance Buckingham 2006, Bawden 2008, or Sefton-Green, Nixon and Erstad 2009). Lankshear and Knobel (2008; 2015) have proposed the term digital literacies (in plural) to account for the "myriad social practices and conceptions of engaging in meaning making mediated by texts that are produced, received, distributed, exchanged etc., via digital codification" (Lankshear and Knobel 2015, 13). While useful due to their contextualisation in terms of a bottom-up perspective on media and technology use, the approach still does not question the wider socio-economic conditions of this use, and how these frame and feed back into the practices of meaning-making identified by the authors.

These aspects are taken up by scholars interested in an explicitly critical notion of digital literacy. Fusing ideas by Lankshear and Knobel with critical approaches, Ávila and Zacher Pandya $(2013,3)$ use the term to account for "those skills and practices that lead to the creation of digital texts that interrogate the world". They write that digital technologies can enable previously disenfranchised students to critique cultural and political frames or challenge authorities in school contexts and beyond. In spite of their focus on both socially and politically embedded practices and empowerment, the element of critiquing the very technologies in use, and their often-ambivalent affordances, ramifications, and conditions of application, falls somewhat short in Ávila and Zacher Pandya's argument.

Such issues are taken up by Buckingham $(2006,264-265)$ who writes that digital literacy needs to include critical components that enable reflection upon how media technologies interfere with personal development and how they "are related to broader 
social, political and economic forces" (2006, 267). In a similar manner, Saariketo $(2014,32)$ has voiced a need for "critical technology education" that manages to complement the transfer of instrumental user skills "with an understanding of how the digital society functions and whose interests steer it", while Hoechsmann and Poyntz (2012, 162-163) point to underlying logics of capitalism as a veritable "elephant in the room" in thinking about technology-use in schools. The two authors show that digital technologies enable "increasing corporate governance of everyday life" $(2012,162)$ and demand critical attention to "how young people's privacy and identity are being shaped by commercial intrusions" (see also Pötzsch 2016).

A critique of commercial intrusion also forms the background of Simanowski's (2018) approach. He argues that critical reflection upon (possibly unintended) consequences of digital technologies does not require the acquisition of costly new products. Neither do we need new skill sets for teachers or new school subjects. Rather, Simanowski continues, critical mindsets can best be achieved by the traditional humanities with their historicising, multi-perspectival, and interpretative approaches, as these methods facilitate reflective critique aimed at Bildung in a Humboldtian understanding where the individual gradually matures through self-reflective engagement with itself and its surroundings, rather than constituting mere tools for Ausbildung with an eye on labour-market qualification and the acquisition of quantifiable human capital.

Such a reflexive criticism aligns well to Luke's (2014) framework. In his definition, critical digital literacy refers to processes of "naming and renaming the world, seeing its patterns, designs and complexities, and developing the capacity to redesign and reshape it" $(2014,29)$. Here, various possible uses of semiotic systems across a variety of modes and media are combined with knowledge acquired for the purpose of empowering people, and enabling subversion and transformative change also in relation to such technologies. In contrast to, for instance, Simanowski, Luke identifies potentials for the appropriation and re-appropriation of digital technologies and extends Ávila and Zacher Pandya's approach by enabling attention to mixed affordances of technologies and the received power structures within which they operate and are operated. However, as for instance Hagood (2013, 221-222) has shown, several obstacles make such a critical use of digital technologies in schools difficult - prime among them are increasing demands for standardised quantifiable assessments with a main focus on merely functional forms of literacy.

One attempt at a summary of the current state of testable standards can be found in the European Commission's Science Service's policy report DigiComp 2.0 (Vuorikari et al. 2016). Here, a conceptual reference model is proposed that divides the arguably confusing field of digital literacy/ies into five distinct dimensions, each covering a series of different key competencies and skills. The framework appears very comprehensive, including such critical aspects as awareness for environmental impacts of digital technologies, attentiveness to possible hazards to physical and psychological wellbeing connected to new media use, and the capacity to manage multiple digital identities and actively seek opportunities for self-empowerment in relation to complex systems. However, in spite of their balanced and at times critical outlook, they direct little attention to alternative media or the economic frames predisposing affordances and possible uses of commercial products. Their main aim is to break down the complex field into isolated testable standards.

Indeed, for many, demands for digital literacy carry with them the question of how new skill sets and competencies can be adequately evaluated and assessed. Much research has therefore been devoted to finding evidence for which technologies work 
and prove most efficient in light of specified, quantifiable objectives (see for instance Golonka et al. 2014). Favoured technologies are often those specifically designed for educational purposes. It is assumed that these will pose least obstacles for implementation and provide the best measurable outputs (see for instance Otnes 2009). Likewise, technologies that are not ready-at-hand but cause frictions, and that do not lead to easily quantifiable results, are often discarded (Sørensen 2009; Beck 2011; Brox 2017). An invisibility of technology seems to imply the successful implementation of a well-functioning and smooth system and emerges as a tacit ideal (Jackson 2014; Edwards 2015).

Approaches demanding increased critical digital literacy are often perceived as topdown prescriptions of what and how schools need to teach without taking actual uses of technologies by pupils sufficiently into account (Sefton-Green, Nixon and Erstad 2009; Ávila and Zacher Pandya 2013; Lankshear and Knobel 2015; Kern 2015; Gangneux 2019). As Gangneux (2019) has shown, actual practices of technology use are often far more varied and reflected than generally assumed. This, however, does not mean to suppose a perfect media competence of so-called digital natives. Gangneux also directs attention to various tacit frames conditioning bottom-up usage of technology across a variety of dimensions, including economic ones, that reveal a need for guidance and critical education. With an eye on such issues, Pangrazio (2016) suggests updating the term 'critical digital literacy'. To enable a critique of digital technology without alienating individual users and their often-ambivalent relations to these technologies, she proposes to balance structural issues of ideology, economy, technology and collective concerns with attention to individual practices and dispositions. Pangrazio advocates "critical digital design" $(2016,170)$ as a practicefocused alternative that combines "understandings of discourse, ideology and power in the digital context" with analysis and production of multimodal texts and focus on how digital infrastructure "manifests and maintains systems of power and privilege" (2016, 170). Combining critique, practice, and self-reflection in this manner, her approach brings to the forefront the various affordances and contexts of our most salient technologies and connects these to situated practices of use and appropriation. As the next section will show, such comprehensive critical approaches are a necessity given the economic frames and political and personal ramifications of wide-spread digitisation under the conditions of contemporary capitalism.

\section{Political Economy, Power, and Agency in Networked Realms}

Structural issues such as economic inequalities, environmental footprints, and new forms of management and control are key aspects to be taken seriously in debates about digital technologies in education and beyond (Pedersen 2008; Jarrett 2008; Fuchs 2012a/b; Gehl 2014; Harcourt 2015; Pötzsch 2016; 2018; Zuboff 2019). Multiple forms of exploitation and accumulation as well as an increasing quantification and subsequent commodification of identities and social relations are not exceptions, but constitute the fundamental logics of operation of digital technologies in contemporary capitalism (Fuchs 2017). This does not only affect societies, politics, and economic organisation, but also has profound implications for the development of individuals towards ideals of emancipation and self-determination. A careful contextualisation of technology can highlight continuities in the apparently new that are usually eschewed in dominant discourses about the digital as immaterial, clean, efficient, and a domain of allegedly unprecedented opportunities (for instances of this thinking, see e.g. Barlow 1996 or Schmidt and Cohen 2013). 
Drawing upon a wide range of available research, Hayles (2012) has observed that the digital devices of the contemporary era exhibit a designed tendency to capture and mould humans' attentive potentials. According to her, digital technologies systematically privilege a cognitive mode called hyper-attention that combines the capacity to superficially scan and quickly map large amounts of information with the ability to make decisions based on intuition. Despite its advantages for orientation in information-rich environments, hyper-attention also exhibits crucial lacks and shortcomings. It is characterised by a lack of depth in analyses, a low threshold for boredom, and an in-built need for constant gratification. Hayles argues that a tacit privileging of this cognitive mode increasingly threatens a second form of informationprocessing characteristic for humans, namely deep attention, that entails the ability to fully indulge in a specific task for an extended period of time to achieve expert knowledge. According to Hayles, the cognitive mode of deep attention is virtually incompatible with the intrinsic logics of digital devices and applications. In this situation, Hayles argues, schools and other educational institutions should be adequately equipped to counter a constant technologically-facilitated push towards hyper-attention and convey knowledge and skills in the purview of the classical humanities with their focus on close reading, interpretation in context, in-depth understanding, and critical reflection. Rather than jumping on the digital bandwagon, schools could constitute an important counter-weight fostering important cognitive modes otherwise underprivileged in contemporary society (Beck 2011; Hayles and Pötzsch 2014; Simanowski 2018).

Hayles $(2012 ; 2016)$ also alerts us to a second important feature of digital domains, namely the increasingly constitutive impact of non-human forms of agency and cognition upon human decisions, relations, identities, and societies. She has shown that the relation between technology and humans always has been reciprocal. From the first stone our ancestors picked up to the most complex digital networks, we have always been formed by the objects we developed to shape our surroundings. Holding a stone, for instance, invites certain practices such as throwing or hitting, while the enabled act of throwing again privileges an erect posture. Such thinking is at the core of the idea that human agency is limited by its material contexts and that humans and technology essentially co-evolve in what Hayles terms "technogenesis".

When seen from this vantage point, what emerges as new to the contemporary digital era is the responsive and adaptable nature of our most salient technologies and the pervasiveness and accuracy with which they analyse us down to the most intimate emotional and affective states, using this information to subsequently nudge us into change. Sticking with the example from above, today, we hold 'stones' that gather and process bodily states, that read hidden preferences, desires, and fears out of our interactions with various online and offline environments, and that follow each and every step we take. Storing and processing all these data, these 'stones' then feed increasingly fine-grained pokes back to us, tacitly nudging us into certain beliefs and performances that shape our identities and societies in the name of predominantly economic interests (Gehl 2014; Harcourt 2015; Hayles 2016; Cheney-Lippold 2017; Mau 2017; Pötzsch 2018). The tacit and proactive data-gathering strategies fuelling these processes are key ingredients of the mind-blowing profit rates of new media giants such as Facebook, Alphabet (owning Google), or Microsoft, and they connect the issue of framed agency and co-evolution back to the field of the economy. This context has inspired Pangrazio and Selwyn (2019) to propose "personal data literacies" as an important aspect of contemporary education that should adequately prepare pupils to manage their own data and take control over their digital alter egos. 
This is not to say that digital technology per se will with necessity foster new forms of exploitation and oppression. As among many others Galloway (2004), Chun (2006), Fuchs (2017), Hayles (2012), and Daum (2019) have pointed out, technologies including digital ones - in themselves are neither liberating nor oppressive. Predominantly contextual factors predispose what use a particular innovation can be put to and how it will operate under specific socio-cultural, economic, and political conditions. As such, awareness for and knowledge about the practices and logics of exploitation, commodification, and profit maximisation underlying contemporary techno-capitalism constitute crucial aspects of literacies, competencies, and skills relevant for the current era. A critical notion of digital and other literacies enables us to productively engage with the inherent ambiguity of technology that always oscillates between the ultimately political poles of freedom and control.

Such ambiguities are reflected in the ways commercial platforms at once enable user agency and control and claim ownership of large amounts of data. To achieve profit, contemporary commercial applications such as Google, Facebook, or Instagram combine two distinct types of archives that I have identified as 1) an "explicit surface archive" and 2) an "implicit deep archive" (Pötzsch 2018, 3311). Normally, users retain considerable control over the explicit dimensions of today's digital archives and can, within limits, actively and autonomously curate their own profiles, images, shares, likes, and files (see Gangneux 2019). The implicit deep archives, on the contrary, tacitly gather and process data that is unwillingly and often unconsciously produced by users interacting in and with various on- and offline domains. These data sets are stored in deep archives owned and controlled by commercial actors that mine them for profit. The user-controlled surface archive and the corporate-owned deep archive are manifestations of the continuous freedom-control dynamic of digital networks identified by, for instance, Galloway (2004) and Chun (2006).

Gray, Gerlitz, and Bounegru $(2018,8)$ have proposed an expansion of the term 'literacy' to adequately respond to this situation. They coin the term "data infrastructure literacy" as the capacity to "account for, inventively respond to and intervene around the socio-technical infrastructures involved in the creation, extraction and analysis of data". In a move reminiscent of Gehl's (2014) notion of "reverse engineering social media", Gray, Gerlitz and Bounegru $(2018,8)$ also include capacities to actively "disassemble data infrastructures" where necessary and to critically address tacit biases and limits inherent in their operations. Data infrastructure literacy, as such, is an important component of critical digital literacy.

When seen from the vantage point of such and other studies, the term critical digital literacy should encompass not only issues such as the ability to produce and decode multimodal documents in transmedia environments, skills in information retrieval and use, knowledge on identity and privacy management, or technical user expertise presented as crucial aspects of the term by, for instance, Lankshear and Knobel (2008; 2015), Vuorikari et al. (2016), and others. In addition, following, for instance, Ávila and Zacher Pandya (2013), Luke (2014) and Pangrazio (2016), the ability to see digital technology in global and local contexts and to retain critical awareness for underlying issues of power in economic and political terms emerge as crucial components - as does the ability to repair, tinker with, resist, or simply avoid these technologies (Simanowski 2018).

In light of what has been said so far, advocating a widened notion of critical literacy relevant for a digital age seems to imply a need to teach about more things within given budgetary and other frames. Does this imply a need for more digital devices in classrooms and teachers with entirely new skill sets? As the concrete 
recommendations in the next section of this article will show, a realisation of aspects of a critical digital literacy does not require access to costly new commercial applications. Neither does it demand new or 'better' educated teachers. Rather, critical, reflective, investigative, and mature mindsets and practices can also, and possibly even better, be fostered through the use of traditional teaching methods or under the application of cheap or even freely available technologies. Therefore, I argue for an adjustment of focus from expensive and intrusive corporate products and new skill sets for teachers to practical solutions within range of most schools and educators under current conditions.

\section{What Is to be Done with the Digital?}

In educational contexts, new technologies are often merely assumed to improve teaching and learning. As scholars such as Selwyn (2010; 2016), Beck (2011), Livingstone (2012), Bigum, Bulfin and Johnson (2015), Bigum and Rowan (2015), Bayne (2015), Simanowski (2018), and Hanell (2018) have shown, critical reflection about whether or not education is in need of improvement at all, how exactly new technologies are meant to contribute, and why the massive investments in new devices are supposed to achieve better results than alternative measures, often remains lacking. The little-questioned and hardly ever seriously debated introduction of products such as Canvas, Chrome Book, Summit or other hard- and software applications across schools and universities worldwide are questionable for several reasons.

First, as these applications usually are hermetically sealed, operate on a turn on/turn off basis, and are characterised by a smooth design that poses few frictions, the technology itself moves into the background and critical understanding of its functionalities and possibilities for tinkering, repair, or hacking are drastically reduced (Sørensen 2009; Beck 2011; Brox 2017; Golden 2017). Therefore, these devices invite only the most basic forms of user engagement and de-emphasise creative testing, play, and re-appropriation of essentially black-boxed technologies. ${ }^{2}$ Not least cases such as the recently mounting resistance against the implementation of the corporate edu-tech platform Summit in Kansas schools (Bowles 2019) raise critical questions. Does a growing reliance upon corporate applications as cheap means to improve quantifiable results constitute the beginning of a new class division in the educational system between automated tech for 'problematic' groups and human-delivered reflective Bildung for the more affluent?

Second, the licensing of commercial products such as ChromeBook, Summit, or Canvas together with the acquisition of tablets and PCs imply significant financial burdens for already-strained educational budgets (Sørensen 2009, 1). While the acquisition of new tools and devices is often covered by fresh funding, subsequent maintenance, service, and repair usually become part of established financial frames. This means that fresh funds for new devices, in the long run, implies less funding for traditional activities (see for instance Bowles 2019). What is often lacking is a critical debate about the actual need for and overall long-term costs of new technologies, about possible alternatives, and about the global human and ecological implications of these large-scale investments in high-tech equipment and the significant resources they require. Uncritical implementation also potentially engenders constant demands

\footnotetext{
2 This might be the reason why digital economy developers and business leaders have become wary of screens and now often send their own children to technology-free Waldorf schools (Bowles 2018; Simanowski 2018, 24).
} 
for the latest innovations, again with the implied concern for lagging behind allegedly ungovernable international developments (Hanell 2018). The availability and functionality of alternative non-commercial products are regularly kept invisible and their installation on sealed and black-boxed corporate hardware is often prevented.

Third, even though authorities at a municipal level may retain control of pupils' profiles on corporate platforms here and now, there are few safeguards ensuring the protection of this data in long-term perspectives. The sheer market value of comprehensive education-related user-data ranging from grades 1 to 13 raises serious reasons for concerns. As for instance Lindh and Nolin (2016) show, based on data from Sweden, commercial giants such as Google or Microsoft deliberately deemphasise the value of user-data for their business models in communications with public institutions and often retain tacit reservations enabling future changes of the status of this data. Furthermore, the increased use of quantifiable data to assess achievements by both teachers and pupils is in need of further critical scrutiny. As Williamson (2015), Lynch (2015; 2017), and Golden (2017) have argued, the increasing datafication of education aimed at fostering, among other things, algorithmic thinking, combined with the growing use of complex algorithms in planning and assessment, can have problematic and unintended consequences that are not yet adequately understood and, therefore, require additional critical reflection prior to implementation.

Fourth, the demand for new skill sets for teachers or the inclusion of new subjects to be taught such as informatics or programming imply a cutting of teaching hours and content in different areas. As, among others, Simanowski (2018) and Selwyn (2016) have pointed out, the subjects most prone to cuts are usually from the humanities or practical disciplines such as literature, the arts, or music, precisely the fields that according to Beck (2011), Hayles (2012) and Simanowski (2018) are key in countering contemporary technologically-facilitated drives towards hyper-attention, fragmentation, and commodification. As such, even though including informatics into the school syllabus might sound like a good idea to improve the labour-market relevance of education, the long-term consequences might be detrimental to the aim of fostering mature, reflective, and critical citizens.

So, what can be done with the digital? I suggest three frameworks for the development of critical digital literacy:

1) the use of and reflection about alternative non-commercial products serving similar functions as their corporate counterparts,

2) direction of attention to the history of 'new' technologies and contemporary data activism and its political practices, and

3 ) the increased use in class of cultural expressions that have issues of power, surveillance, and exploitation in digital domains as their explicit themes.

Some of the proposed methods are suitable for lower grade pupils, while others require more mature and self-determined learners. At least key elements of all the recommended practices can be realised without access to technical tools or new skill sets for teachers.

\section{Fostering Critical Digital Literacy: Non-Commercial Alternatives}

Today, a plethora of commercial hardware and software such as iPads, Chrome Book, Microsoft 365, Summit, or Canvas have been introduced in both schools and academic institutions worldwide. In an educational variant of what Morozov (2013) has termed "digital solutionism", expensive products are advocated as ex-machina quick fixes for ill-defined or even absent problems. Widely available free open-source software 
(FOSS) solutions that are developed through collaborative practices, that are free of charge, and that serve a variety of purposes, are hardly ever mentioned in educationrelated public debate even though these alternatives would save strained educational budgets significant amounts of money and would enable critical reflection regarding genuine advantages but also potential pitfalls of current drives toward digitisation. An overview of examples of available FOSS products relevant for education can be seen in Table 1 below.

\begin{tabular}{|c|c|c|c|c|}
\hline $\begin{array}{l}\text { Shareware } \\
\text { product }\end{array}$ & Function & Use & $\begin{array}{l}\text { Comparable } \\
\text { commercial } \\
\text { product }\end{array}$ & Link \\
\hline Libre Office & $\begin{array}{l}\text { Text editing, } \\
\text { spread-sheets, } \\
\text { presentations, } \\
\text { projects }\end{array}$ & $\begin{array}{l}\text { Full office pack, contains } \\
\text { equivalences of Word, Excel \& } \\
\text { Power Point, and offers special } \\
\text { programmes for math and drawing }\end{array}$ & $\begin{array}{l}\text { Microsoft } \\
\text { Office }\end{array}$ & $\begin{array}{l}\text { Https://www.libreo } \\
\text { ffice.org/ }\end{array}$ \\
\hline Firefox & Web browser & $\begin{array}{l}\text { Browse \& search the world wide } \\
\text { web }\end{array}$ & Safari, Chrome & $\begin{array}{l}\text { https://www.mozill } \\
\text { a.org/en- } \\
\text { US/firefox/ }\end{array}$ \\
\hline $\begin{array}{l}\text { VLC Media } \\
\text { Player }\end{array}$ & Media player & $\begin{array}{l}\text { Plays video and audio files in all } \\
\text { formats }\end{array}$ & $\begin{array}{l}\text { QuickTime } \\
\text { Player }\end{array}$ & $\begin{array}{l}\text { https://www.videol } \\
\text { an.org/vlc/ }\end{array}$ \\
\hline JitsiMeet & $\begin{array}{l}\text { Videoconferenc } \\
\text { es }\end{array}$ & $\begin{array}{l}\text { Browser-based videoconferencing } \\
\text { tool for multiple users (no } \\
\text { installation necessary), fully } \\
\text { encrypted, no data collection }\end{array}$ & Skype & https://meet.jit.si/ \\
\hline Wikipedia & Encyclopaedia & $\begin{array}{l}\text { Online encyclopaedia summarising } \\
\text { knowledge in various fields. Highly } \\
\text { transparent with regards to } \\
\text { knowledge production. Enables } \\
\text { reading, writing, corrections \& } \\
\text { debate. }\end{array}$ & $\begin{array}{l}\text { Encyclopaedia } \\
\text { Britannica }\end{array}$ & $\begin{array}{l}\underline{\text { https://en.wikipedi }} \\
\underline{\text { a.org/wiki/Main P }} \\
\underline{\text { age }}\end{array}$ \\
\hline DuckDuckGo & Search engine & $\begin{array}{l}\text { Search the Internet, no data } \\
\text { collection \& no customisation of } \\
\text { search results }\end{array}$ & Google & $\begin{array}{l}\text { https://duckduckg } \\
\underline{\text { o.com/ }}\end{array}$ \\
\hline Tor & Web browser & $\begin{array}{l}\text { Browse \& search the world wide } \\
\text { web, fully encrypted, anonymises } \\
\text { all online activity, hides IP address }\end{array}$ & None & $\begin{array}{l}\text { https://www.torpro } \\
\text { ject.org/ }\end{array}$ \\
\hline we.riseup.net & Wiki creator & $\begin{array}{l}\text { Collaborative writing, team } \\
\text { projects, creation of websites }\end{array}$ & $\begin{array}{l}\text { Microsoft } \\
\text { Teams }\end{array}$ & $\underline{\text { https://riseup.net/ }}{ }^{*}$ \\
\hline share.riseup.net & $\begin{array}{l}\text { File sharing } \\
\text { application }\end{array}$ & $\begin{array}{l}\text { Sharing of text documents, } \\
\text { images, videos \& more }\end{array}$ & DropBox & $\underline{\text { https://riseup.net }}{ }^{*}$ \\
\hline pad.riseup.net & Etherpad & $\begin{array}{l}\text { Collaborative writing, team project } \\
\text { coordination }\end{array}$ & GoogleDocs & https://riseup.net/ ${ }^{*}$ \\
\hline Signal & Messaging app & $\begin{array}{l}\text { Send and receive text messages } \\
\text { and other data. Fully encrypted, no } \\
\text { data gathering. }\end{array}$ & Messenger & $\frac{\text { https://signal.org/d }}{\underline{\text { ownload/ }}}$ \\
\hline Diaspora* & $\begin{array}{l}\text { Social } \\
\text { networking } \\
\text { platform }\end{array}$ & $\begin{array}{l}\text { Creation of social networks, } \\
\text { posting of information and } \\
\text { documents, social organisation. } \\
\text { No data gathering, no ads. }\end{array}$ & Facebook & $\begin{array}{l}\text { https://diasporafou } \\
\text { ndation.org/ }\end{array}$ \\
\hline Galaxy 2 & $\begin{array}{l}\text { Social } \\
\text { networking } \\
\text { platform }\end{array}$ & $\begin{array}{l}\text { Creation of social networks, } \\
\text { posting of information and } \\
\text { documents, social organisation. } \\
\text { No data gathering, no adds. } \\
\text { Located on dark web. }\end{array}$ & Facebook & $\begin{array}{l}\text { http://w363zoq3yl } \\
\frac{\text { ux5rf5.onion }}{\text { (requires Tor }} \\
\text { browser) }\end{array}$ \\
\hline
\end{tabular}

Table 1: FOSS versus commercial applications with relevance for education

All the applications in the table above are ready to use and can be downloaded from the Internet free of charge. Updates and patches are made available on a regular basis by FOSS collectives. In case of technical problems, wikis and online fora offer quick and reliable help and explanations. The first four products, Libre Office, Firefox, VLC 
Media Player, and JitsiMeet can be used to replace costly commercial solutions in terms of text-editing and presenting, Internet browsing, the playing of $a / v$ files, and video-conferencing. The applications run smoothly and without changing the user experience in a significant manner.

Mozilla's non-profit web browser Firefox can be used to replace commercial browsers such as Safari or Google Chrome. However, Firefox does not by default protect user data. To ensure a higher degree of privacy a series of add-ons need to be installed that are available on the website of the developers and that can easily be plugged in and used. Among the most important extensions available are https everywhere (defaults all web-traffic to an encrypted format), Adblock plus (creates an opt-in solution for web-based advertising), Privacy Badger (hampers data collection on users), and Google as well as Facebook Containers (isolating Google's and Facebook's data gathering to single tabs). These add-ons and many more can be installed at the push of a button and work as background features that do not need any further attention.

The alternative search engine Duck Duck Go can replace commercial products such as Google or Yahoo. In contrast to the latter two, Duck Duck Go does not pass user data on and refrains from tailoring results with reference to individual profiles and other available data. An interesting task in school might be to compare search results from commercial and non-commercial engines. This enables critical perspectives on the necessity to weight data protection and user privacy against user convenience and the perceived relevance of acquired results. The exercise can then be extended to discussions on how other commercial content providers such as Facebook, Amazon or Netflix employ user data to customise and filter recommendations, and address implications of these practices in terms of cultural diversity, inclusion, and democratic debate on an increasingly fragmented public sphere (O'Neil 2016).

The free online encyclopaedia Wikipedia has a series of functionalities that open up additional educational potentials compared to its commercial counterparts. Affordances such as the anonymous editing of entries, history pages showing all past edits, and discussion pages where debates over the content and form of entries can be conducted, invite teachers and learners to critically reflect upon and actively engage in processes of knowledge production and curation usually eschewed in traditional dictionaries. As such, Wikipedia enables an understanding of knowledge as a continuously evolving non-linear process, rather than the accumulation of ever-more accurate, allegedly objective facts. Through editing exercises with or without support from the Wikipedia commons, pupils can be brought to critically reflect upon their own everyday usage of the platform, fostering new and possibly more active forms of contribution and engagement (see Brox 2012).

The free web browser Tor (The Onion Router) enables virtually full anonymity online by veiling devices' IP addresses (provided browsing habits are adjusted accordingly and log-ins to commercial applications such as Facebook or YouTube are avoided). Introduction and use of the Tor browser can be accompanied by discussions about advantages and disadvantages of privacy in online environments highlighting issues such as democratic deliberation, responsible use, or possibilities for crime and harassment opened up by anonymity. The task can also address different meanings of the term privacy at play in debates about online anonymity (Fuchs 2012b).

Alternative social media (ASM) such as Diaspora * or Galaxy 2 are easy to use and provide most features of their profit-oriented counterparts while protecting user privacy from commercial or state intrusion (see Gehl and Synder-Yuly 2016). Galaxy 2 is located on the dark web to enhance privacy and user-control. Therefore, the latter 
requires the Tor browser for access and might be more difficult to use in school. For a selection of additional alternatives, see the Social Media Alternatives project (SMAP) by Robert Gehl. ${ }^{3}$ Possible uses in educational contexts might include comparisons between a selected ASM and commercial counterparts familiar to students. This comparison can gradually extend focus from technical features, affordances, and perceived user-friendliness toward organisational aspects such as relations of production behind the application, institutional and technical infrastructure, issues of funding and economic sustainability, as well as analyses of terms of service agreements and other juridical frames.

A peculiar challenge for ASMs is the comparably low number of users they attract compared to their commercial competitors. The value of networking sites, both economically and in terms of usage, is dependent upon their members. Presentations of ASMs in school need to take this into account and connect the introduction of the suggested alternative to specific tasks such as class coordination or the teaching of particular subject matter. By these means, students can be made aware of alternatives and enabled to test these out without confining them to an alternative "ghetto", identified by the Comedia group (1984) in relation to the non-mainstream press. More traditional approaches to digital and information literacy can use ASMs as a mere backdrop to develop more conscientious, reflected, and critical uses of dominant commercial applications among pupils and students, and explore the possibilities of resisting and re-appropriating their commercialising dynamics from within.

A concerned teacher might ask what will happen if available FOSS applications do not work properly. In this case, many online fora and discussion groups can offer quick and reliable supervision and support. However, even in case either technology or pupils do not behave as planned, precisely this malfunctioning can be made the subject of teaching efforts that can attempt to analyse why things do not work and what made pupils behave the way they did, inviting them at the same time to offer concrete alternatives to improve the situation. Issues such as the co-constitutive relation between human users and technology can be made an explicit theme (Sørensen 2009) and usually smoothly operating technologies can be foregrounded and made the object of critical inquiry with an eye on both open and hidden affordances (for the case of Wiki technology in teacher education, see Brox 2017).

In sum, simply installing and running FOSS applications might avoid costs for schools and universities but does not by itself foster a critical form of digital literacy. To enhance such capacities among pupils or students, the process of identifying and applying non-commercial products needs to be accompanied by critical reflection about key differences distinguishing them from their commercial counterparts not only with regard to efficacy and use-value but also with an eye on socio-economic contexts of production, commodification, maintenance, and use. By means of a wide and accessible FOSS infrastructure, genuinely progressive potentials of digital networks inviting collaboration and cooperative practices can be fleshed out, and can subsequently be contrasted with corporate products and their profit-oriented logics. At the same time, non-commercial products also deserve critical scrutiny. Most of the collectives behind alternative applications rely on donations and free labour by volunteers who are often caught up in self-exploitative dynamics. For the reflective tasks outlined above, the programmes under scrutiny need not necessarily be installed and used, but can also be addressed in a merely theoretical manner, for instance, with reference to alternative media theory (Comedia 1984; Gehl 2015). This way the

${ }^{3}$ The S-MAP can be accessed here: https://www.socialmediaalternatives.org/?page id=2 
freedom-control dynamics of the contemporary Internet can be made palpable by means of either theoretical reflection or reflected practical use.

\section{Fostering Critical Digital Literacy: Political and Historical Embedding and Contextualisation}

One possible way of increasing critical reflection among pupils and students about the emergence and further development of contemporary digital networks is a careful historicising of the technology itself as well as of the institutions behind it, and discourses around it (see for instance Comedia 1984; Pickard 2015; Starosielski 2015; Hayles 2012; Abbate 2017). How were earlier communication systems developed? How did their gradual spreading interfere with politics, the economy, or practices of identity construction? Who profited from the innovations? Were there alternatives? Identified historical analogies can then be brought to bear upon a critical reassessment of the Internet and its history as a technology originally conceived by the Pentagon and further developed by a complex meshwork of military interests, tech businesses, academics, activists, and users (see for instance Abbate 2000; 2017; Turner 2006; Galloway 2004). In a similar manner, Facebook's self-promotion of aiming at creating community can be critically interrogated with an eye on the economic incentives of the platform and its financially-motivated push toward generating revenue-creating clicks regardless of content (see Gehl 2014; Harcourt 2015; Herrman 2016; Lanchester 2017). This engenders the question of what exactly Facebook might mean by terms such as community or privacy and what alternative definitions of the terms do exist (see Fuchs 2012b; 2017 and Fenton 2016). Traditional methods from the humanities can provide viable tools to define and critically reassess such apparently common-sensical terms.

Historical parallels can also be identified at a level of discourse. How have past technologies been talked about? How have their possibilities and potential hazards been treated in the news media, public policy papers, statements by politicians, critical scholars, corporate think-tanks, or advertisers? Again, after excursions into historical precedents, discourses about contemporary technologies can productively be disentangled and connected to possible financial or other interests (Selwyn 2016; Fuchs 2017; Hanell 2018). Here in particular, evident contradictions between statements about and the factual performances of new media can be critically interrogated and contextualised with the help of texts ranging from Brecht's (2000) by now classic thoughts on radio technology, via Comedia's (1984) critique of alternative print media, to Andrejevic's (2009) early critique of surveillance through digital television or Pickard's (2015) history of US radio that shows clear parallels to challenges posed by contemporary 'new' technologies.

Such historical approaches can be combined with critical investigations of the global political economy behind familiar digital devices such as smartphones or laptop computers focusing on relations and sites of production, distribution, use, and waste management (see for instance Maxwell and Miller 2012; Qiu 2016; Weigensamer and Krönes 2018). Through brief play of the freely available digital game Phonestory, produced by the Italian game design collective Molleindustria (2011) under a creative commons license, pupils can be alerted to the vast underbelly of gritty material production underlying apparently readily-available, clean, and smooth digital machines. ${ }^{4}$ Themes that can be addressed in connection to gameplay range from the working conditions and environmental tolls on extraction sites of rare earth metals, via

\footnotetext{
${ }^{4}$ The game can be freely accessed and downloaded here: http://www.phonestory.org/
} 
systematic exploitation of labour in global manufacturing and distribution chains, problematic patterns of use, and issues of addiction, to the detrimental societal and ecological consequences of recycling efforts at the receiving end of Western countries' electronic waste. The game's website contains additional resources on key issues taken up in the game and also features a walk-through that can be used by teachers to access all levels for preparation without playing through the game. Efforts such as these can be further facilitated by bringing broken devices to school that can be opened up in attempts to identify key components, their sources, and potential implications for the environment in a practical hands-on approach.

In light of recent discussions on politics and disinformation in digital domains, issues of hate speech, fake news and tacit propaganda can also be rearticulated in class, problematising for instance a simplifying unilateral assigning of responsibility for a deteriorating state of public debate in Western democracies to alleged interventions of malign foreign powers. By scrutinising the technical, economic, and political dynamics behind such issues, attention can be redirected to the various incentives and interests driving discursive moves of othering and exclusion (see for instance George 2016 or Herrman 2016). None of these exercises requires access to digital tools. As Simanowski $(2018,204)$ writes, "filter bubbles and fake news $[\ldots]$ are not only combatted on screens or on the Internet, but first and foremost through the education of mature subjects". ${ }^{5}$

If one aims at sensitising pupils and students to the scale of data collection executed by commercial actors such as Facebook and Alphabet (Google), the Guardian newspaper has published a detailed guide with explanations and links on how to check exactly what data the companies have stored about users (Curran 2018). ${ }^{6}$ The provided tools are largely self-explanatory, a fact that allows learners to autonomously test out and explore the various data sets, enabling an increased awareness of how their digital alter egos are composed and how much information about them is in fact available to commercial actors in and through the applications pupils use on a daily basis. This critical reflection about their own everyday practices can then be further contextualised with reference to business models and forms of exploitation and commodification in the digital economy (Fuchs 2017). In case pupils do not have access to their own devices, teachers can project their own efforts on screen and demonstrate the tools before directing discussions towards implications of the findings at personal and collective levels. Additionally, attention to a new form of "somatic surveillance" identified by Hayles $(2016,43)$ as automated registering of nonconscious expressions of inner states through body language, changes in heart rate, body temperature, breathing, and other phenomena can be connected to the exercise to enable discussions about future opportunities and threats of Fitbits and other increasingly automated socio-technical surveillance and feedback systems.

Additional resources useful for the development and acquisition of critical digital literacy can be acquired from a variety of civil society organisations such as the Electronic Frontier Foundation (EFF), the Chaos Computer Club (CCC), or Netzpolitik. $\mathrm{org}^{7}$. These organisations can offer quick and cost-free support in a variety

${ }^{5}$ German original: "Filterblasen und Falschmeldungen [...] bekämpft man nicht nur am Bildschirm und im Internet, sondern vor allem durch die Erziehung zum mündigen Subjekt".

${ }^{6}$ Curran's article and compilation of links can be accessed here: https://www.theguardian.com/commentisfree/2018/mar/28/all-the-data-facebook-google-has-on-you-privacy

7 These organisations' webpages can be accessed here: https://www.eff.org/ (Electronic Frontier Foundation), https://www.ccc.de/en/club (Chaos Computer Club), and https://netzpolitik.org/ (Netzpolitik.org). 
of fields and can be approached by teachers or pupils in educational concerns as well. In schools, the work done by these organisations also invites discussions about the significance, for functioning democracies, of citizen privacy and the freedom to organise and gather information beyond the reach of corporate bodies and state agencies.

\section{Fostering Critical Digital Literacy: Creative Responses in Art, Media, and Politics}

As argued above, digital devices do not need to be available in classrooms to guide pupils and students toward a more reflected and critical attitude toward these technologies. One possible alternative is to recur back to cultural expressions (literature, films, art works, television series) that take up key features of the digital era in a reflected manner. One example would be the art installation Autonomy Cube (2014) by US photographer and activist Trevor Paglen, who is famous for, among other things, his attempts to visually document the physical infrastructure of contemporary US secret service activities (Paglen 2009; 2014). ${ }^{8}$ The autonomy cube is an artwork to be exhibited in galleries and museums. It consists of several computer mainframes that are located in a white rectangular sculpture with a transparent top. Through its visual appearance, the installation makes a point about white-boxing otherwise closedoff digital technologies. The artwork, however, also has direct performance effects. The computers inside are fully functional and constitute a mobile Wi-Fi hot spot. The Internet connection is open, fully encrypted, and uses the Tor network to enable anonymous browsing on the web. In addition, the autonomy cube functions as a Tor relay facilitating anonymous net traffic by other Tor users. Discussion of an artwork such as this in lessons can open up a series of important issues regarding technology, state power, contemporary activism, and the potential pitfalls of both surveillance and anonymity in digital domains. After discussing the general political and societal implications taken up by Paglen, advanced courses could move on to build or plan their own autonomy installation, or discuss the double-sided nature of artistic works as both representation and inherently political performance (see Paglen and Gach 2003).

Alternatively, film can be used to convey background information on specific relevant cases that are then contextualised and expanded upon in class. Laura Poitras's Citizenfour (2014) provides an excellent opening for engagements with the 2013 US National Security Agency (NSA) surveillance scandal. The documentary film consists of original footage Poitras had taken when she, together with then Guardian reporters Glenn Greenwald and Ewen MacAskill, met whistle-blower Edward Snowden in Hong Kong. The film meticulously documents the background, gradual unfolding, and implications of one of the most significant revelations of recent political history and throws a sharp light on the massive surveillance conducted by the NSA on behalf of the US government. After the screening, original NSA documents released by Snowden can be investigated that are currently accessible via a variety of sources. ${ }^{9}$

\footnotetext{
${ }^{8}$ More information on Paglen's projects can be accessed here: http://paglen.com/

${ }^{9}$ Documentation and additional information on the 2013 global surveillance disclosure can be accessed via the websites of The Guardian newspaper (https://www.theguardian.com/world/interactive/2013/nov/01/snowden-nsa-files-surveillance-revelations-decoded\#section/3), WikiLeaks (https://wikileaks.org/the-spyfiles.html), and the American Civil Liberties Union (https://www.aclu.org/nsa-documents-search). For a concise overview and some background documentation and historical precedents, see Wikipedia (https://en.wikipedia.org/wiki/Global surveillance disclosures (2013\%E2\%80\%93present) and https://en.wikipedia.org/wiki/Global surveillance disclosures (1970\%E2\%80\%932013)).
} 
Eventually, focus can be directed to historical precedents (e.g. Daniel Ellsberg's Pentagon papers) and other contemporary cases of whistle-blowing such as the leaking by Chelsea Manning of classified diplomatic cables sent from US embassies across the world to the State Department. The documents were redacted and published by WikiLeaks in the fully searchable database PlusD that, according to Assange $(2015,11)$, enables analyses of US foreign policy that have "not been hobbled by the censorship of classified materials" (for a user manual, see Harrison 2015). ${ }^{10}$

Contemporary challenges with regard to surveillance, management, exploitation, and control can be read and re-assessed through the lens of works of literature dealing with similar issues such as George Orwell's 1984 (1949) or, to provide a more contemporary example, Dave Eggers' The Circle (2013). These examples show that critical digital literacy does not necessarily depend on access to new technologies or new skill sets, but can easily be fostered and facilitated with traditional methods in classic humanities subjects such as film or literary studies.

One key asset of digital technologies is the fact that they undermined the gatekeeping function of traditional media channels and enabled audiences, albeit in limited form, to combine the roles of receiver and producer of media messages. This key characteristic can be harnessed for educational purposes by opening opportunities for student-driven active creation of expressions documenting, for instance, their own practices with and attitudes towards digital technologies. By these means the creative use of devices for content creation can be productively combined with critical reflection and subsequent potential appropriation.

By means such as those proposed above, key skills, competencies, and knowledge regarding contemporary communication networks can be conveyed, and critical reflection on this technology and its possible implications on societal, political, economic as well as individual levels can be facilitated. In some cases, the availability of digital tools in the classroom is an advantage or even required. In others, however, important educational goals regarding 'the digital' can easily be achieved without access to technical devices and under application of 'classical' teaching methods.

\section{Conclusion}

In the present article I have addressed issues of literacy in terms of contemporary digital networks. Recalling key tenets of theoretical debates about the term, I traced a gradual expansion of the concept's range of address from reading and writing skills via communication in various modes and media, ending up with a notion of critical digital literacy that combines reflective user skills with critical awareness of digital technologies' wider societal, political, economic, cultural, and environmental implications. Subsequently, I critiqued current discourses and practices of technologyinclusion in schools and universities as precisely lacking such critical aspects. Finally, I offered a series of concrete hands-on recommendations for teachers and learners on how to foster and convey such extended and reflective knowledges, competencies, and skills. One key aspect of the argument was that formation and development of

First Look Media the company behind the online publication channel The Intercept, that was originally established to sift through, evaluate, and subsequently publish the trove of documents handed over by Snowden, announced on March 13, 2019 that it closes its NSA archive and lays off the group of investigators working with the material, most notably Laura Poitras and Glenn Greenwald. The source material leaked by Snowden remains in the hands of the two journalists (see Tani 2019).

10 The Public Library of US Diplomacy can be accessed here: https://www.wikileaks.org/plusd/about/ 
critical digital literacy can be achieved within contemporary budgetary and organisational frames and do not require new technological tools in classrooms or new skill sets for teachers.

In sum, critical and reflective use of digital technologies in education and in society at large requires more than access to corporate hard and software. Inherently blackboxed technologies need to be opened up, contextualised, and critically questioned to retain democratic control over their personal, socio-political, economic, and cultural ramifications. In this context, not only do instrumental user skills with an eye on the presumed requirements of a future labour market appear as crucial for the acquisition of digital literacy, but in particular the ability to critically assess, appropriate, and, if need be, replace, repair, or resist such technologies emerge as key for the formation a self-determined future citizenry.

\section{References}

Abbate, Janet. 2017. What and Where Is the Internet? (Re)defining Internet Histories. Internet Histories: Digital Technology, Culture \& Society 1 (1-2): 8-14.

Abbate, Janet. 2000. Inventing the Internet. Cambridge, MA: The MIT Press.

Andrejevic, Mark. 2009. The Twenty-First Century Telescreen. In Television Studies After TV: Understanding Television in the Post-Broadcast Era, edited by Graeme Turner and Jinna Tay, 31-40. London: Routledge.

Assange, Julian. 2015. Introduction: WikiLeaks and Empire. In The WikiLeaks Files: The World According to US Empire, edited by Julian Assange, 1-19. London: Verso.

Ávila, JuliAnna and Jessica Zacher Pandya. 2013. Traveling, Textual Authority, and Transformation: An Introduction to Critical Digital Literacies. In Critical Digital Literacies as Social Praxis: Intersections and Challenges, edited by JuliAnna Ávila and Jessica Zacher Pandya, 1-14. New York: Peter Lang.

Barlow, John Perry. 1996. A Declaration of Independence of Cyberspace. Eff.org, February 8. Accessed August 8, 2019. https://www.eff.org/de/cyberspace-independence

Bawden, David. 2008. Origins and Concepts of Digital Literacy. In Digital Literacies: Concepts, Policies and Practices, edited by Colin Lankshear and Michele Knobel, 17-32. New York: Peter Lang.

Bayne, Sian. 2015. What's the Matter with Technology-Enhanced Learning? Learning, Media \& Technology 40 (1): 5-20.

Beck, Eevi. 2011. Computers in Education: What for? Nordic Journal of Digital Literacy (special issue): 282-293.

Bigum, Chris and Leonie Rowan. 2015. Gorillas in Their Midst: Rethinking Educational Technology. In Critical Perspectives on Technology and Education, edited by Scott Bulfin, Nicola F. Johnson and Chris Bigum, 15-34. New York: Palgrave Macmillan.

Bigum, Chris, Scott Bulfin and Nicola F. Johnson. 2015. Critical Is Something Others (Don't) Do: Mapping the Imaginative of Educational Technology. In Critical Perspectives on Technology and Education, edited by Scott Bulfin, Nicola F. Johnson and Chris Bigum, 113. New York: Palgrave Macmillan.

Bowles, Nellie. 2018. A Dark Consensus About Screens and Kids Begins to Emerge in Silicon Valley. The New York Times, October 26. Accessed August 8, 2019. https://www.nytimes.com/2018/10/26/style/phones-children-silicon-valley.html?module=inline

Bowles, Nellie. 2019. Silicon Valley Came to Kansas Schools. That Started a Rebellion. The New York Times, April 21. Accessed August 8, 2019. https://www.nytimes.com/2019/04/21/technology/silicon-valley-kansasschools.html?utm source=pocket-newtab

Brecht, Bertolt. 2000. The Radio as Communications Apparatus. In Brecht on Film and Radio, edited by Marc Silbermann, 41-47. New York: Bloomsbury. 
Brox, Hilde. 2017. What's in a Wiki? Issues of Agency in Light of Student Teachers' Encounters with Wiki Technology. Nordic Journal of Digital Literacy 12 (4): 129-142.

Brox, Hilde. 2012. The Elephant in the Room: A Place for Wikipedia in Higher Education? Nordlit 30: 143-155. Accessed August 8, 2019. https://septentrio.uit.no/index.php/nordlit/article/view/2377/2195

Buckingham, David. 2007. Beyond Technology: Children's Learning in the Age of Digital Culture. Cambridge: Polity Press.

Buckingham, David. 2006. Defining Digital Literacy: What Do Young People Need to Know about Digital Media? Digital Kompetanse 1 (4): 263-276.

Cazden, Courtney, Bill Cope, Norman Fairclough, and Jim Gee. 1996. A Pedagogy of Multiliteracies: Designing Social Futures. Harvard Educational Review 66 (1): 60-92.

Cheney-Lippold, John. 2017. We Are Data: Algorithms and the Making of Our Digital Selves. New York: New York University Press.

Chun, Wendy Hui Kyong. 2006. Control and Freedom: Power and Paranoia in the Age of Fibre Optics. Cambridge, MA: The MIT Press.

Comedia. 1984. The Alternative Press: The Development of Underdevelopment. Media, Culture \& Society 6 (2): 95-102.

Curran, Dylan. 2018. Are You Ready? Here Is All the Data Facebook and Google Have on You. The Guardian, March 30. Accessed August 9, 2019. https://www.theguardian.com/commentisfree/2018/mar/28/all-the-data-facebook-googlehas-on-you-privacy

Daum, Timo. 2019. Die künstliche Intelligenz des Kapitals. Hamburg: Edition Nautilus.

Edwards, Richard. 2015. Software and the Hidden Curriculum in Digital Education. Pedagogy, Culture \& Society 23 (2): 265-279.

Eggers, Dave. 2013. The Circle. New York: Knopf Doubleday.

Erstad, Ola. 2015. Educating the Digital Generation. Nordic Journal of Digital Literacy 5 (1): 56-71.

Fenton, Natalie. 2016. Digital, Political, Radical. Cambridge: Polity Press.

Fuchs, Christian. 2017. Social Media: A Critical Introduction. London: Sage. Second edition.

Fuchs, Christian. 2012a. Google Capitalism. tripleC: Communication, Capitalism \& Critique 10 (1): 42-48.

Fuchs, Christian. 2012b. The Political Economy of Privacy on Facebook. Television \& New Media 13 (2): 139-159.

Galloway, Alexander. 2004. Protocol: How Control Exists After Decentralization. Cambridge, MA: The MIT Press.

Gangneux, Justine. 2019. Logged in or Locked in? Young Adults' Negotiations of Social Media Platforms and Their Features. Journal of Youth Studies 22 (8): 1053-1067.

Gehl, Robert W. 2015. The Case for Alternative Social Media. Social Media \& Society (JulyDecember): 1-12.

Gehl, Robert W. 2014. Reverse Engineering Social Media: Software, Culture, and Political Economy in New Media Capitalism. Philadelphia, PA: Temple University Press.

Gehl, Robert W. and Julie Synder-Yuly. 2016. The Need for Social Media Alternatives. Democratic Communiqué 27: 78-82.

George, Cherian. 2016. Hate Spin: The Manufacture of Religious Offense and Its Threat to Democracy. Cambridge, MA: The MIT Press.

Golden, Noah A. 2017. Critical Digital Literacies across Scales and beneath the Screen. Educational Media International 54 (4): 373-387.

Golonka, Ewa M., Anita R. Bowles, Victor M. Frank, Dorna L. Richardson and Suzanne Freynik. 2014. Technologies for Foreign Language Learning: A Review of Technology Types and Their Effectiveness. Computer-Assisted Language Learning 27 (1): 70-105.

Gray, Jonathan, Carolin Gerlitz and Liliana Bounegru. 2018. Data Infrastructure Literacy. Big Data \& Society 5 (2). https://doi.org/10.1177/2053951718786316 
Hagood, Margaret C. 2013. Afterword: So Now You Know. What Are You Going to Do about It? In Critical Digital Literacies as Social Praxis: Intersections and Challenges, edited by JuliAnna Ávila and Jessica Zacher Pandya, 219-223. New York: Peter Lang.

Hanell, Fredrik. 2018. What Is the 'Problem' that Digital Competence in Swedish Teacher Education Is Meant to Solve? Nordic Journal of Digital Literacy 13 (3): 137-151.

Harcourt, Bernard E. 2015. Exposed: Desire and Disobedience in the Digital Age. Cambridge: Harvard University Press.

Harrison, Sarah. 2015. Indexing the Empire. In The WikiLeaks Files: The World According to US Empire, edited by Julian Assange, 145-158. London: Verso.

Hayles, N. Katherine. 2016. Cognitive Assemblages: Technical Agency and Human Interactions. Critical Inquiry 43 (1): 32-55.

Hayles, N. Katherine. 2012. How We Think: Digital Media and Contemporary Technogenesis. Chicago: The University of Chicago Press.

Hayles, N. Katherine and Holger Pötzsch. 2014. Posthumanism, Technogenesis, and Digital Technologies: A Conversation with N. Katherine Hayles. The Fibreculture Journal 23: 95107.

Herrman, John. 2016. Inside Facebook's (Totally Insane, Unintentionally Gigantic, Hyperpartisan) Political-Media Machine. The New York Times Magazine Online, August 24. Accessed on August 9, 2019. https://www.nytimes.com/2016/08/28/magazine/inside-facebooks-totally-insane-unintentionally-gigantic-hyperpartisan-political-media-machine.html

Hoechsmann, Michael and Stuart R. Poyntz. 2012. Media Literacies: A Critical Introduction. Chicester: Wiley-Blackwell.

Jackson, Steve J. 2014. Rethinking Repair. In Media Technologies: Essays Communication, Materiality, and Society, edited by Tarleton Gillespie, Pablo J. Boczkowski and Kirsten A. Foot, 221-240. Cambridge, MA: The MIT Press.

Jarrett, Kylie. 2008. Interactivity is Evil! A Critical Investigation of Web 2.0. First Monday 13 (3), https://firstmonday.org/article/view/2140/1947.

Kern, Richard. 2015. Language, Literacy, and Technology. Cambridge: Cambridge University Press.

Kress, Gunther. 2003. Literacy in the New Media Age. London: Routledge.

Lanchester, John. 2017. You Are the Product. London Review of Books 39 (16): 3-10.

Lankshear, Colin and Michele Knobel. 2015. Digital Literacy and Digital Literacies: Policy, Pedagogy and Research Considerations for Education. Nordic Journal of Digital Literacy $10(1): 8-20$.

Lankshear, Colin and Michele Knobel. 2008. Introduction: Digital Literacies - Concepts, Policies and Practices. In Digital Literacies: Concepts, Policies and Practices, edited by Colin Lankshear and Michele Knobel, 1-16. New York: Peter Lang.

Lindh, Maria and Jan Nolin. 2016. Information We Collect: Surveillance and Privacy in the Implementation of Google Apps for Education. European Educational Research Journal 15 (6): 644-663.

Livingstone, Sonia. 2012. Critical Reflections on the Benefits of ICT in Education. Oxford Review of Education 38 (1): 9-24.

Livingstone, Sonia. 2004. Media Literacy and the Challenge of New Information and Communication Technologies. The Communication Review 7 (1): 3-14.

Luke, Allan. 2014. Defining Critical Literacy. In Moving Critical Literacies Forward: A New Look at Praxis across Contexts, edited by Jessica Pandya and JuliAnna Ávila, 19-31. London: Routledge.

Lynch, Tom Liam. 2017. Below the Screen: Why Multiliteracies Research Needs to Embrace Software. English Journal 106: 92-94.

Lynch, Tom Liam. 2015. Soft(a)ware in the English Classroom: Mustard Seeds and Information Feeds: A Short History of Students as Data. English Journal 105: 96-98.

Mau, Steffen. 2017. Das Metrische Wir: Über die Quantifizierung des Sozialen. Frankfurt am Main: Suhrkamp Verlag. 
Maxwell, Richard and Toby Miller. 2012. Greening the Media. Oxford: Oxford University Press.

Molleindustria. 2011. Phonestory [game].

Morozov, Evgeny. 2013. To Save Everything, Click Here: Technology, Solutionism, and the Urge to Fix Problems that Don't Exist. London: Allen Lane.

O'Neil, Cathy. 2016. Weapons of Math Destruction. New York: Penguin.

Orwell, George. 1949. 1984. London: Secker \& Warburg.

Otnes, Hildegunn. 2009. A være digital. [Being Digital]. In $\AA$ være digital $i$ alle fag. [Being Digital in All Subjects], edited by Hildegunn Otnes, 11-29. Oslo: Universitetsforlaget.

Paglen, Trevor. 2014. New Photos of the NSA and Other Top Intelligence Agencies Revealed for the First Time. The Intercept, February 10. Accessed August 9, 2019. https://theintercept.com/2014/02/10/new-photos-of-nsa-and-others/

Paglen, Trevor. 2009. Blank Spots on the Map: The Dark Geography of the Pentagon's Secret World. New York: Penguin Group.

Paglen, Trevor and Aaron Gach. 2003. Tactics Without Tears. The Journal of Aesthetics and Protest 1(2): n.p. Accessed August 9, 2019. http://www.joaap.org/1/TacticsWithout/index.html

Pangrazio, Luciana. 2016. Reconceptualising Critical Digital Literacy. Discourse: Studies in the Cultural Politics of Education 37 (2): 163-174.

Pangrazio, Luciana and Neil Selwyn. 2019. Personal Data Literacies: A Critical Literacies Approach to Enhancing Understandings of Personal Digital Data. New Media \& Society 21 (2): 419-437.

Pedersen, Søren Mørk. 2008. Loser Generated Content: From Participation to Exploitation. First Monday 13 (3). Accessed on August 9, 2019. https://firstmonday.org/article/view/2141/1948

Pickard, Victor. 2015. America's Battle for Media Democracy: The Triumph of Corporate Libertarianism and the Future of Media Reform. Cambridge: Cambridge University Press.

Poitras, Laura. 2014. Citzenfour. New York: Praxis Film.

Pötzsch, Holger. 2018. Archives and Identity in the Context of Social Media and Algorithmic Analytics: Towards an Understanding of iArchive and Predictive Retention. New Media \& Society 20 (9): 3304-3322.

Pötzsch, Holger. 2016. Materialist Perspectives on Digital Technologies: Informing Debates on Digital Literacy and Competence. Nordicom Review 37 (1): 119-132.

Qiu, Jack. 2016. Goodbye iSlave: A Manifesto for Digital Abolition. Urbana, IL: University of Illinois Press.

Saariketo, Minna. 2014. Imagining Alternative Agency in Techno-Society: Outlining the Basis of Critical Technology Education. In Media Practice and Everyday Agency in Europe, edited by Leif Kramp, 129-138. Bremen: Edition Lumière.

Schmidt, Eric and Jared Cohen. 2013. The New Digital Age: Reshaping the Future of People, Nations, and Businesses. New York: Random House.

Sefton-Green, Julian, Helen Nixon and Ola Erstad. 2009. Reviewing Approaches and Perspectives on Digital Literacy. Pedagogies: An International Journal 4 (2): 107-125.

Selwyn, Neil. 2016. Minding Our Language: Why Education and Technology Is Full of Bullshit... and What Might Be Done About It. Learning, Media \& Technology 41 (3): 437443.

Selwyn, Neil. 2010. Looking beyond Learning: Notes towards the Critical Study of Educational Technology. Journal of Computer Assisted Learning 26 (1): 65-73.

Simanowski, Roberto. 2018. Stumme Medien: Vom Verschwinden der Computer in Bildung und Gesellschaft. Berlin: MSB Matthes \& Seitz.

Sørensen, Estrid. 2009. The Materiality of Learning: Technology and Knowledge in Educational Practice. Cambridge: Cambridge University Press.

Starosielski, Nicole. 2015. The Undersea Network. Durham, NC: Duke University Press. 
Tani, Maxwell. 2019. The Intercept Shuts Down Access to Snowden Trove. The Daily Beast, March 13. Accessed August 9, 2019. https://www.thedailybeast.com/the-intercept-shutsdown-access-to-snowden-trove?ref=scroll

Turner, Fred. 2006. From Counterculture to Cyberculture: Stewart Brand, the Whole Earth Network, and the Rise of Digital Utopianism. Chicago, IL: University of Chicago Press.

Vuorikari, Riina, Yves Punie, Stephanie Carretero, and Lieve van den Brande. 2016. DigiComp 2.0: The Digital Competence Framework for Citizens. Brussels: Joint Research Centre of the European Commission. Accessed August 9, 2019. http://publications.jrc.ec.europa.eu/repository/bitstream/JRC101254/jrc101254 digcomp\%202.0\%20the\%20digital\%20competence\%20framework\%20for\%20citizens.\%20update\%20phase\%201.pdf

Weigensamer, Florian and Christian Krönes. 2018. Welcome to Sodom. Stuttgart: Camino Filmverleih.

Williamson, Ben. 2015. Governing Software: Networks, Databases and Algorithmic Power in the Digital Governance of Public Education. Learning, Media \& Technology 40 (1): 83105.

Zuboff, Shoshana. 2019. The Age of Surveillance Capitalism: The Fight for a Human Future at the New Frontier of Power. London: Profile Books.

\section{About the Author}

Holger Pötzsch

Holger Pötzsch, PhD, is associate professor in Media and Documentation Studies at UiT The Arctic University of Norway (Troms $\varnothing$ ) and visiting scholar at the Dept. of Communication Studies at Ludwig-Maximilians-University Munich. He holds an MA in Peace and Conflict Studies and a PhD in Media and Documentation Studies. Pötzsch has done research on media, politics, and conflict and has published on themes such as the war film, war games, critical and material aspects of digital technologies, as well as on border culture and technologies of bordering. 